\title{
Publication and Language Trends of References in Spanish and Latin American Literature
}

\author{
David S. Nolen
}

This study examined references found in three journals in the field of Spanish and Latin American literary studies. Few previous studies have examined types of publishers producing highly cited/referenced books. The data indicate that the primary publishers of scholarly monographs referenced in the journals are U.S. university presses, foreign academic trade presses, and foreign popular trade presses. U.S. university presses, foreign academic trade presses, and government entities published most of the volumes of collected essays referenced. Scholarly monographs published outside the U.S. represented the largest proportions of references, with large growth in references to volumes of collected essays published in the United States. References to English-language materials increased significantly from 1970 to 2000 .

\section{Introduction and Statement of the Problem}

Collection development decisions present librarians with a variety of dilemmas. The selection function requires knowledge of the discipline and the community being served, and this knowledge guides subject bibliographers' decisions. Nonetheless, the intuition and expertise of the selector, although well-informed, may not adequately address the concerns of interested administrators and stakeholders, especially in an environment of increased financial accountability. In addition, not all librarians who are charged with making selection decisions for a given discipline have a background in that area.

Bibliometric data about what scholars working in a given field are citing or referencing in their own research can be helpful to subject specialists and other selectors in their selection decisions. Previous citation and reference studies have increased the library profession's knowledge of scholarly practices in a number of disciplines, including those traditionally categorized as humanities. A 2005 study by Knievel and Kellsey affirmed high usage of book-format resources across eight humanities fields. ${ }^{1}$ Further studies have indicated that volumes of collected essays - not only scholarly monographsare important book sources for scholars in at least certain fields of literary scholarship. ${ }^{2}$ A number of studies also indicate that the book produced by a university press is the most important vehicle for scholarly communication in many humanities disciplines. ${ }^{3}$ These studies also caution that there may be considerable

David S. Nolen is Assistant Professor and Assistant Editor/Reference Librarian in the Ulysses S. Grant Presidential Library/Congressional and Political Research Center, Mississippi State University Libraries; e-mail: dnolen@library.msstate.edu. (C) 2014 David S. Nolen, Attribution-NonCommercial (http:// creativecommons.org/licenses/by-nc/3.0/) CC BY-NC 
variations in citation patterns across research areas in the humanities.

A field like Spanish and Latin American literature provides an interesting set of challenges for selectors. As in other humanities disciplines, researchers in this field depend on book-format resources, ${ }^{4}$ but the more specific citation patterns in this field may vary from those in other humanities disciplines. For example, because of its focus on more international subject matter, it seems safe to assume that scholars working in this discipline would use many materials published overseas and a high percentage of foreignlanguage sources, with possibly lower use of university press items than researchers in other disciplines. But are these assumptions correct? For experienced and novice selectors, more detailed data about the characteristics of the materials referenced in Spanish and Latin American literary scholarship can provide an additional tool for making selection decisions, as well as providing supporting data for accountability purposes.

This study began as an opportunity to test some of these assumptions about scholarship in Spanish and Latin American literature and thereby gather helpful data for selection and acquisitions decisions. The primary goal of this study is to provide greater detail of the characteristics of references to book-format sources in the field of Spanish and Latin American literature by reporting the number of references by type of publisher, geographic origin, and by language of publication. This analysis sheds light on the publication origins of those materials, as well as the degree to which English-language resources are referenced in the literature of the discipline. These kinds of data, taken together, can be a useful resource for librarians working as selectors for Spanish and Latin American literature.

\section{Literature Review}

\section{Types of Press}

Although previous scholarship has examined similar questions for other fields in the humanities, none have used the same methodology or taken exactly the same focus as the current study. Nonetheless, a number of articles provide helpful context for some of the questions raised here. As mentioned above, recent scholarship on citation patterns in the humanities has affirmed what numerous earlier studies have found: the book-format item is the chief vehicle for scholarly communication in the humanities. ${ }^{5}$

Few studies have looked at the types of publishers producing highly cited/referenced books. Most of those mentioned here have attributed significant importance to university press books, although the methodologies used have varied. In his 1992 study of scholarly books in fine arts, Cullars concluded that university presses published most of the books produced for that discipline in a given year. He obtained a sample of scholarly books in the fine arts by searching RILA, an international database of art scholarship. University press publications constituted 50.6 percent of the 158 books included in his sample. ${ }^{6}$ Another study by Metz and Stemmer measured the reputation of university presses. They found that collection development librarians held university presses in high regard, with librarians in their sample consistently ranking university presses at the top in terms of familiarity, relevance, and quality. ${ }^{7}$

Other studies have examined measures of circulation and reached similar conclusions: scholars in humanities fields use items published by university presses regularly. One study focusing on usage of resources in the humanities categorized patron materials requests by publisher. In this study, Broadus reported data gleaned from the book and article requests by visiting scholars researching at the National Humanities Center in North Carolina. He found that university press publications made up 34.8 percent of all requested monographs. ${ }^{8}$ Saunders' 1996 study compared the circulation statistics for titles from university presses and other publishers. He found that university press 
titles circulated at about the same rate as scholarly books published by commercial houses, ${ }^{9}$ highlighting the continued importance of university presses in producing content for the scholarly community.

Studies by Cullars and Thompson have further explored usage of university press books by looking at citation data by publisher. It is helpful to clarify that these two projects represent distinct approaches in their application of bibliometrics: one is a reference study, and the other is a citation study. Throughout the remaining discussion, the author of the current study will use these terms as defined below to distinguish these methodologies. Cullars' 1998 article examining philosophy monographs is more precisely defined as a reference study, because he counted each in-text reference to a work. His data thus reflect a greater weight for sources that are referenced more frequently. Using that methodology, he found that U.S. and foreign university press publications comprised 41.5 percent of the books referenced by those monographs in his sample. ${ }^{10}$

In her study of British and American literary studies, Thompson counted only the first mention of a source and did not count subsequent references to that title, thereby weighting each source equally in the aggregated data. This methodology is best described as a citation study. Thompson found that university presses accounted for seventeen of the twentyfour publishers identified as core publishers of monographs and collected essays in the field of British and American literary studies, affirming that the products of university presses are highly cited in that discipline. ${ }^{11}$

Two related studies explored more focused areas within humanities disciplines. In their 2006 study of citation patterns in the journal literature of Latin American history, Mendez and Chapman found that university presses produced the bulk of monographs cited as secondary sources in the journal Hispanic American Historical Review. Although Mendez and Chapman counted all references to a given source, they only used the number of individual titles cited (not references) in compiling their publisher data. ${ }^{12}$ By contrast, Ardanuy, Urbano, and Quintana reported that commercial publishers produced 78 percent of the cited documents in their study of Catalan literature, with only 21 percent of sources being published by scholarly or governmental entities. ${ }^{13}$ These variations in methodologies and findings further reinforce the need for more studies of related humanities disciplines.

\section{Language of Source}

A number of citation and reference studies in the humanities have included data regarding the language of the material being cited or referenced. Each of the studies listed below used slightly different methodologies, making direct comparison difficult. Nonetheless, their findings present a broad perspective on language of resources referenced or cited in various humanities disciplines. Two studies have found high usage of English-language resources across humanities disciplines. In their study of four fields within the humanities (history, classics, linguistics, and philosophy), Kellsey and Knievel found that citations to English-language sources made up a significant and generally increasing percentage of total citations over time. However, the authors concluded that citations to foreign-language materials continued to be important. Specifically, the percentage of articles without citations to foreign-language materials decreased from 1962 to 2002 when they examined the aggregate data. ${ }^{14}$

Knievel and Kellsey found similar numbers in their 2005 study of eight humanities fields. In the fields of art, classics, history, linguistics, literature, music, philosophy, and religion, an average of 78.2 percent of citations were to Englishlanguage materials, with a range of 65.3 percent (art) to 99.7 percent (philosophy). In spite of these overall high numbers for citations to English-language materials 
across the humanities, the study also revealed a greater importance of foreign language materials in specific disciplines, with no one foreign language dominating across the different fields. The data for literature citations (gleaned from articles that appeared in the journal $P M L A$ ) indicated 83.8 percent of all citations were to English-language sources. ${ }^{15}$

The studies that addressed specific areas within the humanities found varying language patterns. Heinzkill's 1980 study of footnotes in English literary journals found few citations to non-English materials ( $9 \%$ of total citations). ${ }^{16}$ Likewise, Broadus reported English-language materials comprised 94.4 percent of the requests by research fellows working in the subject discipline of English literature at the National Humanities Center (NHC). English-language materials accounted for 82.3 percent of total requests by all research fellows at the NHC. ${ }^{17}$ With a narrow focus on English-language literature, these results would not necessarily be unexpected, but Broadus' percentage reflecting all the humanities fellows' requests points to heavy usage of English-language materials across other disciplines within the humanities as well.

Several of Cullars' reference studies deserve special attention because of the way he recorded language data for each project. His 1988 study of the use of foreign language materials by native-English speakers researching foreign-language literature reported that sources in languages other than English made up 64 percent of all references. As Cullars mentioned, this percentage could be expected since the language of the principal criticism of a literary work is naturally related to the language of the work itself. Although his data reflected high use of sources in the language of the text of study, English-language materials formed the largest overall group of sources, with roughly 36 percent of total references to English-language sources. Cullars also documented an anticipated relationship among the native language of the scholar (in this case,
English), the language of the topic, and the language of the material referenced: scholars in his sample rarely referenced sources that were written in a language that was not English or the language of the subject matter (less than $2 \%$ ). ${ }^{18}$

Cullars found a similar presence of English-language sources in his 1989 study of French and German literary monographs. English sources comprised the most referenced language group after sources in either French or German, depending on the language of the monograph being studied. ${ }^{19}$ He found that scholars studying Spanish literature referenced primarily Spanish-language resources in a subsequent study of Italian and Spanish monographs, but Englishlanguage resources were the second-most referenced language category. In the same study, books written in Italian referenced primarily Italian sources, followed by French sources. The Italian literary scholars used English-language sources less frequently. ${ }^{20}$ In Cullars' 1992 study of the reference patterns in fine arts monographs, English was the primary language of references, although sources in German and several Romance languages made up nearly 38 percent of all references. ${ }^{21}$

Two recent studies of very specific areas within the humanities have reported language data that is relevant. Mendez and Chapman examined the language of cited monographs in their study of Latin American history. They found that citations to English language monographs rose from 37.4 percent in their sample from 1985 to 63.3 percent in 1995, with a drop to 58.1 percent of the total in their 2005 sample. $^{22}$ In their study of Catalan literary studies, Ardanuy, Urbano, and Quintana reported that citations to English-language resources were rare. The predominant language of references that focused on Catalan literature was Catalan (86.1\%), while 37.2 percent of references to supplementary sources (such as literary theory or other humanities topics) were in Spanish, with Catalan sources being the next largest language group. ${ }^{23}$ 


\section{Methodology}

The author of the current study used data gathered from three journals in the field of Spanish and Latin American literature to analyze publication and language characteristics of resources. He selected Revista Iberoamericana, Hispania, and Hispanic Review for use in a previous study, ${ }^{24}$ and he gathered the data for this study at the same time as the data for that earlier study. These three journals are three of the most highly cited journals in the field based on a Cited Reference Search in the Arts and Humanities Citation Index, and each one includes articles encompassing a broad array of topics from Spanish and Latin American literature. The examination centered on the 1970 and 2000 volumes of each of these journals, with selection of articles of literary criticism and analysis for the sample. This study can technically be categorized as a reference study because the total count included all references to a given work, whether they appeared in footnotes, endnotes, or in subsequent in-text references. Although labor-intensive, this methodology provides a clearer picture of the impact of a frequently referenced source.

The data reported here focus on only a subset of the data from the previous study of Spanish and Latin American literary studies: the references that fell into the categories of scholarly monographs and volumes of collected essays. The initial data collection included the name of the publisher, the place of publication, and the language of the referenced source. Using similar categories for publishers as Cullars' 1998 study and Georgas and Cullars' 2005 study as a guide, ${ }^{25}$ this study divided the recorded publishers into eleven general categories: U.S. university presses; foreign university presses; U.S. academic institutions and departments; foreign academic institutions and departments; U.S. academic trade presses; foreign academic trade presses; U.S. popular trade presses; foreign popular trade presses; government entities; specialized presses; and joint presses.
The author used a variety of resources to identify presses mentioned in the bibliographic citation information for a resource and to determine its characteristics for the best categorization. The resources Literary Market Place and International Literary Market Place proved useful for getting a general idea about the intended audience and scope of an individual press. Publisher web pages and catalogs provided additional insight into the nature of publications produced by a given publishing house.

The parameters of the aforementioned categories warrant further explanation. United States and foreign university presses are generally easily identified in a bibliographic citation. In this study, these references are separated from those that reference an institution of higher learning, a research center or institute, or an academic department within a college or university as the publisher. This clarifies the true impact of the university press by separating out university publications that do not pass through that specific publishing gateway.

Although the traditional mission of the university press (to publish scholarly works of limited commercial appeal) has evolved considerably over time, ${ }^{26}$ the difference between commercial publications destined for broad markets and scholarly publications aimed at more specialized markets remains a useful distinction. The key difference between the categories of academic and popular trade presses in this study is based on information about the markets of those presses. For example, the author categorized a trade press whose catalog listed titles of mostly academic (and thereby limited) interest as an academic trade press, while he categorized a press that predominantly published works of general interest with the occasional academic title as a popular trade press. To be more specific, the category of popular trade presses included any publishers that produced significant numbers of children's and self-help books. However, this distinction should not be 
misconstrued to imply that publishers categorized as academic trade presses would never publish a work with popular appeal, or that popular trade presses would not publish works of a more academic nature.

An important question regarding this categorization relates to fiction publishing. The category of popular trade presses included any presses that published predominantly general interest fiction, as they typically also published heavily in the areas of children's books and selfhelp. However, a number of presses in this sample published some fiction titles, alongside works of literary criticism and other more scholarly literary studies. Generally, the fiction published by these presses had a much more limited appeal (for example, contemporary, experimental authors) or was composed of selected critical editions of classic literary works. The current study categorizes these publishers as academic trade presses in that their fiction publications were intended for a narrower, scholarly audience.

The category for government entities includes agencies funded by national, regional, or local governments that have a specialized interest in the subject matter at hand, but are not traditional university, academic, or trade presses. The category of specialized presses represents publishers that only publish content with certain topical relevance, such as scholarly/professional associations and religious presses. This project defines any bibliographic citation listing two or more publishing houses as a joint press publication. The author tabulated references to all of these different categories in Excel spreadsheets.

\section{Results and Discussion}

\section{Type of Press}

Table 1 reflects the compiled data for references to scholarly monographs from the three journals from 1970 and 2000. The most dramatic difference from 1970 to

\begin{tabular}{|l|c|c|c|c|}
\hline \multicolumn{4}{|c|}{ Comparison of Scholarly Monograph data from 1970 and 2000 } \\
\hline & \multicolumn{2}{|c|}{$\begin{array}{c}\text { Scholarly Monographs, } \\
\mathbf{1 9 7 0}\end{array}$} & $\begin{array}{c}\text { Scholarly Monographs, } \\
\mathbf{2 0 0 0}\end{array}$ \\
\cline { 2 - 5 } & $\begin{array}{c}\text { Raw } \\
\text { Numbers }\end{array}$ & Percentage & $\begin{array}{c}\text { Raw } \\
\text { Numbers }\end{array}$ & Percentage \\
\hline U.S. University Presses & 71 & $21.8 \%$ & 310 & $26.2 \%$ \\
\hline Foreign University Presses & 25 & $7.7 \%$ & 68 & $5.7 \%$ \\
\hline $\begin{array}{l}\text { U.S. Academic Institutions and } \\
\text { Departments }\end{array}$ & 4 & $1.2 \%$ & 3 & $0.0 \%$ \\
\hline $\begin{array}{l}\text { Foreign Academic Institutions } \\
\text { and Departments }\end{array}$ & 6 & $1.8 \%$ & 77 & $6.5 \%$ \\
\hline U.S. Academic Trade Presses & 9 & $2.8 \%$ & 46 & $3.9 \%$ \\
\hline Foreign Academic Trade Presses & 86 & $26.4 \%$ & 255 & $21.5 \%$ \\
\hline U.S. Popular Trade Presses & 20 & $6.1 \%$ & 51 & $4.3 \%$ \\
\hline Foreign Popular Trade Presses & 55 & $16.9 \%$ & 219 & $18.5 \%$ \\
\hline Government Entities & 9 & $2.8 \%$ & 57 & $4.8 \%$ \\
\hline Specialized Presses & 33 & $10.1 \%$ & 82 & $6.9 \%$ \\
\hline Joint Presses & 8 & $2.4 \%$ & 16 & $1.3 \%$ \\
\hline Totals & $\mathbf{3 2 6}$ & $\mathbf{1 0 0 . 0 \%}$ & $\mathbf{1 1 8 4}$ & $\mathbf{1 0 0 . 0 \% *}$ \\
\hline *Does not equal exactly 100\% due to rounding. & & & \\
\hline
\end{tabular}


2000 is in the overall number of references to scholarly monographs. The articles referenced scholarly monographs only 326 times in the 1970 data, but the data from 2000 reflect over three and a half times that number of references. The count includes references for sixty-three articles from the year 1970, and seventy-seven articles from the year 2000 . The difference of fourteen articles from 1970 to 2000 does not proportionally match the change in references, so the raw numbers indicate a significant increase in the number of references to scholarly monographs.

The data also demonstrate interesting changes in category proportions. Six of the eleven categories exhibited a decrease in percentage of total references from 1970 to 2000, with foreign academic trade presses (one of the most referenced categories) declining by 4.9 percent, which was the largest percentage change of any category. The other two most referenced categories-U.S. university presses and foreign popular trade presses-grew in percentage of references from 1970 to 2000, with U.S. university presses having the most notable growth between the two. In both the 1970 and the 2000 data, U.S. university presses, foreign academic trade presses, and foreign popular trade presses combined accounted for roughly two-thirds of total references.

Table 2 represents the 1970 and 2000 collected essay data. The tremendous growth in the raw numbers of references looks very similar to the data for scholarly monographs, with volumes of collected essays being referenced over five times more frequently in the 2000 data than in the 1970 data. When compared to the small percentage changes in the data for scholarly monographs, the growth trends by category of publisher look very different. Eight of the eleven categories demonstrate growth from the 1970 to 2000 numbers and percentages, with only foreign academic trade presses, foreign popular trade presses, and specialized presses showing percentage declines.

\begin{tabular}{|l|c|c|c|c|}
\hline \multicolumn{5}{|c|}{ TABLE 2 } \\
\hline & Collected Essays, 1970 & \multicolumn{2}{|c|}{ Collected Essays, 2000 } \\
\hline & $\begin{array}{c}\text { Raw } \\
\text { Numbers }\end{array}$ & Percentage & $\begin{array}{c}\text { Raw } \\
\text { Numbers }\end{array}$ & Percentage \\
\hline U.S. University Presses & 13 & $13.8 \%$ & 134 & $26.6 \%$ \\
\hline Foreign University Presses & 3 & $3.2 \%$ & 22 & $4.4 \%$ \\
\hline $\begin{array}{l}\text { U.S. Academic Institutions and } \\
\text { Departments }\end{array}$ & 0 & $0.0 \%$ & 2 & $0.0 \%$ \\
\hline $\begin{array}{l}\text { Foreign Academic Institutions and } \\
\text { Departments }\end{array}$ & 3 & $3.2 \%$ & 44 & $8.7 \%$ \\
\hline U.S. Academic Trade Presses & 3 & $3.2 \%$ & 31 & $6.2 \%$ \\
\hline Foreign Academic Trade Presses & 41 & $43.6 \%$ & 71 & $14.1 \%$ \\
\hline U.S. Popular Trade Presses & 2 & $2.1 \%$ & 31 & $6.2 \%$ \\
\hline Foreign Popular Trade Presses & 16 & $17.0 \%$ & 33 & $6.5 \%$ \\
\hline Government Entities & 4 & $4.3 \%$ & 73 & $14.5 \%$ \\
\hline Specialized Presses & 9 & $9.6 \%$ & 47 & $9.3 \%$ \\
\hline Joint Presses & 0 & $0.0 \%$ & 16 & $3.2 \%$ \\
\hline Totals & $\mathbf{9 4}$ & $\mathbf{1 0 0 . 0 \%}$ & $\mathbf{5 0 4}$ & $\mathbf{1 0 0 . 0 \% *}$ \\
\hline *Does not equal exactly 100\% due to rounding. & & & \\
\hline
\end{tabular}


Two of these declines are, however, quite precipitous, with foreign popular trade presses falling as a percentage of total references by 10.5 percent and foreign academic trade presses falling by 29.5 percent. Meanwhile, U.S. university presses and government entities grew by the greatest percentages, 12.8 percent and 10.2 percent respectively. The three largest categories represent 74.4 percent of total references in the 1970 data and 55.2 percent of total references in the 2000 data.

The data from both scholarly monographs and collected essays indicate a continuing presence in the field of Spanish and Latin American literature for U.S. university press publications. Scholarly monographs published by foreign academic and popular trade presses are frequently cited, with collected essays published by government entities showing the most growth and importance alongside U.S. university presses.

The data presented in these tables affirm that university press publications are important in this field, although the numbers may lend credence to the idea that their usage is less than in other fields. As a percentage of total references (both scholarly monographs and volumes of collected essays), the percentage of items published by university presses grew from 26.7 percent in 1970 to 31.6 percent in 2000 . On the surface, the usage of university press publications appears lower in the current data than the usage presented in previous studies. Cullars' study of philosophy monographs reported 41.5 percent of total references were to university press books, and 70.8 percent of the core publishers identified in Thompson's study were university presses. ${ }^{27}$ Likewise, Broadus and Cullars found higher proportions of university press publications using very different metrics. ${ }^{28} \mathrm{~A}$ more direct comparison is impossible due to differing methodologies and differences in ways the data were reported, but the impression of lesser use of these publications in the current data warrants further exploration of levels of use.

Cullars' findings regarding the prevalence of joint U.S./U.K. publications in philosophy differ from the pattern in the current study. Cullars' study found that joint U.S./U.K. publishing ventures accounted for 26.4 percent of referenced books, while the numbers for joint press publications are considerably lower in the data presented here (see tables 1 and 2). ${ }^{29}$ The data analysis of individual presses and geography presented below does not

\begin{tabular}{|l|c|c|c|c|}
\hline \multicolumn{5}{|c|}{ TABLE 3 } \\
Number of Presses Referenced \\
\hline & \multicolumn{2}{|c|}{ Essays } & \multicolumn{2}{c|}{ Collected Essays } \\
\hline & $\mathbf{1 9 7 0}$ & $\mathbf{2 0 0 0}$ & $\mathbf{1 9 7 0}$ & $\mathbf{2 0 0 0}$ \\
\hline US University Presses & 14 & 42 & 5 & 30 \\
\hline Foreign University Presses & 10 & 16 & 2 & 11 \\
\hline US Academic Institutions and Departments & 2 & 1 & 0 & 2 \\
\hline Foreign Academic Institutions and Departments & 5 & 20 & 2 & 15 \\
\hline US Academic Trade Presses & 6 & 13 & 2 & 10 \\
\hline Foreign Academic Trade Presses & 28 & 44 & 15 & 23 \\
\hline US Popular Trade Presses & 6 & 21 & 1 & 6 \\
\hline Foreign Popular Trade Presses & 23 & 54 & 10 & 22 \\
\hline Government Entities & 6 & 13 & 4 & 19 \\
\hline Specialized Presses & 11 & 27 & 6 & 20 \\
\hline Totals & $\mathbf{1 1 1}$ & $\mathbf{2 5 1}$ & $\mathbf{4 7}$ & $\mathbf{1 5 8}$ \\
\hline
\end{tabular}




\begin{tabular}{|l|c|c|c|}
\hline \multicolumn{4}{|c|}{ TABLE 4 } \\
\hline Frequently Cited/Referenced Publishers of Scholarly Monographs, 2000 \\
\hline Publisher & $\begin{array}{c}\text { \# of Titles } \\
\text { Cited }\end{array}$ & $\begin{array}{c}\text { \# of } \\
\text { References }\end{array}$ & $\begin{array}{c}\text { \% of Total } \\
\text { References }\end{array}$ \\
\hline Routledge & 19 & 44 & $3.8 \%$ \\
\hline Fondo de Cultura Económica & 16 & 23 & $2.0 \%$ \\
\hline Princeton University Press & 12 & 45 & $3.9 \%$ \\
\hline Cambridge University Press & 11 & 26 & $2.2 \%$ \\
\hline Indiana University Press & 10 & 15 & $1.3 \%$ \\
\hline Éditions du Seuil & 9 & 34 & $2.9 \%$ \\
\hline 82 presses with between 2 and 8 titles cited & 288 & 606 & $51.9 \%$ \\
\hline 163 presses with 1 title cited & 163 & 375 & $32.1 \%$ \\
\hline Totals & $\mathbf{5 2 8}$ & $\mathbf{1 1 6 8}$ & $\mathbf{1 0 0 . 0 \%}$ \\
\hline *Does not equal exactly 100\% due to rounding. & & \\
\hline
\end{tabular}

include the joint press numbers because of the inherent difficulties in categorizing those items. However, the later language analysis does incorporate the joint press data.

\section{Individual Presses}

The preceding tables present data broken down by general category of publisher. Examination of the overall distribution of references by individual presses revealed some additional nuances in these data. Initially, one goal of the study was to find individual presses that produced the most references in an attempt to identify core publishers of highly referenced books as in Thompson's study. ${ }^{30}$ However, the data revealed wider distribution than expected. Table 3 presents these data in the most concise manner by simply highlighting the number of individual presses whose works were referenced at least once. The numbers indicate a much greater number of presses in the 2000 data than in the 1970 data.

The number of titles by a particular press cited in the data provided clarity on the presence of individual presses. There was a clear threshold for publishers of scholarly monographs in terms of number of titles cited. Only six presses had nine or more titles cited (see table
4). These six presses reflected only 16.1 percent of the total references to scholarly monographs from the year 2000, with the remaining 245 presses accounting for the remainder of the total references (excluding the data for joint press publications). Eighty-two presses had between two and eight titles cited in the data, with 606 references or 51.9 percent of the total. The remaining 163 presses had only one title represented in the data; 375 references to those titles made up roughly 32 percent of all references.

Table 5 illustrates a similar scenario with volumes of collected essays. Only three presses had eight or more titles cited. References to those titles comprised only 11.4 percent of total references to volumes of collected essays. Thirty-six presses had between two and five titles cited in the data, representing 203 references to those titles (41.6 percent of the total). The vast majority (119 presses) had only one title cited in the data and accounted for 229 references or approximately 47 percent of total references to volumes of collected essays.

Based on these data, the impressive growth in raw numbers of references from 1970 to 2000 was a product of the incorporation of products from a wider variety of presses, and not only growth 


\begin{tabular}{|l|c|c|c|}
\hline \multicolumn{4}{|c|}{ TABLE 5 } \\
Frequently Cited/Referenced Publishers of Collected Essays, 2000 \\
\hline Publisher & $\begin{array}{c}\text { \# of Titles } \\
\text { Cited }\end{array}$ & $\begin{array}{c}\text { \# of } \\
\text { References }\end{array}$ & $\begin{array}{c}\text { \% of Total } \\
\text { References }\end{array}$ \\
\hline Fondo de Cultura Económica & 9 & 29 & $5.9 \%$ \\
\hline SUNY University Press & 8 & 17 & $3.5 \%$ \\
\hline Editorial Milá & 8 & 10 & $2.0 \%$ \\
\hline 36 presses with between 2 and 5 titles cited & 107 & 203 & $41.6 \%$ \\
\hline 119 presses with 1 title cited & 119 & 229 & $46.9 \%$ \\
\hline Totals & $\mathbf{2 5 1}$ & $\mathbf{4 8 8}$ & $\mathbf{1 0 0 . 0 \%}$ \\
\hline *Does not equal exactly 100\% due to rounding. & & & \\
\hline
\end{tabular}

in references to particular presses. With the relatively small data set from the 1970 volumes of collected essays and the dramatic increase to references to these materials in the 2000 data, it is not necessarily unexpected that there would be more variety in the presses represented. Overall, this diversity of publishers contrasts somewhat with Thompson's ability to identify core publishers in the field of nineteenth-century British and American literary studies. ${ }^{31}$

\section{Geography of Publications}

While the individual presses represented in the references are more diverse in the 2000 data than in the 1970 data, the overall geographic trends look somewhat differ- ent. The comparison of the geographic origins of scholarly monographs from 1970 to 2000 indicates almost complete continuity from the regional perspective (see figure 1). Table 6 further breaks down the geographic origins of those scholarly monographs published outside the United States, and the 2000 data indicate that many of these materials are coming from the same countries as those represented in the 1970 data. A notable area of growth is in the increase in the number of references to materials published in Great Britain. References to monographs published in Great Britain and Spain account for 50.5 percent of total references in the 2000 data. The remaining approximate 49.5 percent is rather diverse geographically,

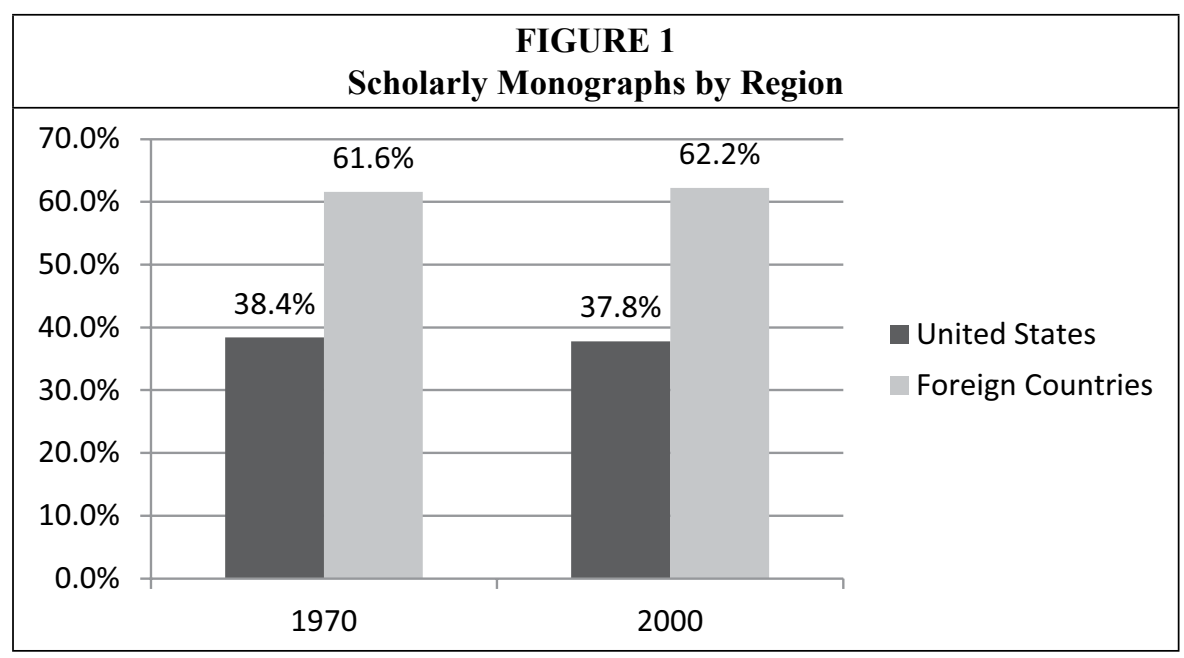




\begin{tabular}{|l|c|c|}
\hline \multicolumn{3}{|c|}{ TABLE 6 } \\
References to Foreign \\
Scholarly Monographs by Country \\
of Publication \\
\hline & $\mathbf{1 9 7 0}$ & $\mathbf{2 0 0 0}$ \\
\hline Argentina & $9.7 \%$ & $10.3 \%$ \\
\hline Brazil & $10.2 \%$ & $5.9 \%$ \\
\hline France & $10.7 \%$ & $8.8 \%$ \\
\hline Great Britain & $10.2 \%$ & $22.8 \%$ \\
\hline Mexico & $7.7 \%$ & $12.1 \%$ \\
\hline Spain & $36.2 \%$ & $27.7 \%$ \\
\hline Other Countries* & $15.3 \%$ & $12.2 \%$ \\
\hline Totals & $\mathbf{1 0 0 . 0} \%$ & $\mathbf{1 0 0 . 0} \% \dagger$ \\
\hline *10 other countries in 1970 data, 12 other \\
$\begin{array}{l}\text { countries in } 2000 \text { data. } \\
\dagger \text { Does not equal exactly } 100 \% \text { due to rounding. }\end{array}$ \\
\hline
\end{tabular}

with references to monographs from sixteen different nations represented.

Overall, the data for references to collected essays show much more change during the 1970-2000 period than the data for scholarly monographs. There is a different regional pattern, with considerable growth in references to materials published within the United States from 1970 to 2000 (see figure 2). Table 7 presents data that illustrate the geographic origins of materials published outside the United States, with declines in terms of percent-

ages for some countries (Spain and Italy), while references to materials published in Mexico increased as a percentage. Like the data for references to scholarly monographs, collected essays from just two countries (Mexico and Spain) make up nearly half $(48.0 \%)$ of the total in the data from 2000. Publications from sixteen other countries make up the remaining 52.0 percent.

It is interesting to note the divergent trends between references to scholarly monographs and those to volumes of collected essays. For scholarly monographs, the bulk of references were to items published outside the United States in both the 1970 and 2000 data. By contrast, references to volumes of collected essays published within the United States grew substantially from 1970 to 2000 . Exactly what factors are involved in this shift is not readily apparent from the data, but these differences do highlight the overall complexity of reference patterns in this field.

Previous studies provide data from other fields that can be used for comparative purposes. Cullars examined geography of publishing to a certain extent in his studies of fine arts and philosophy monographs. In terms of U.S. and overseas publishing, he found that references to materials published in the U.S. made

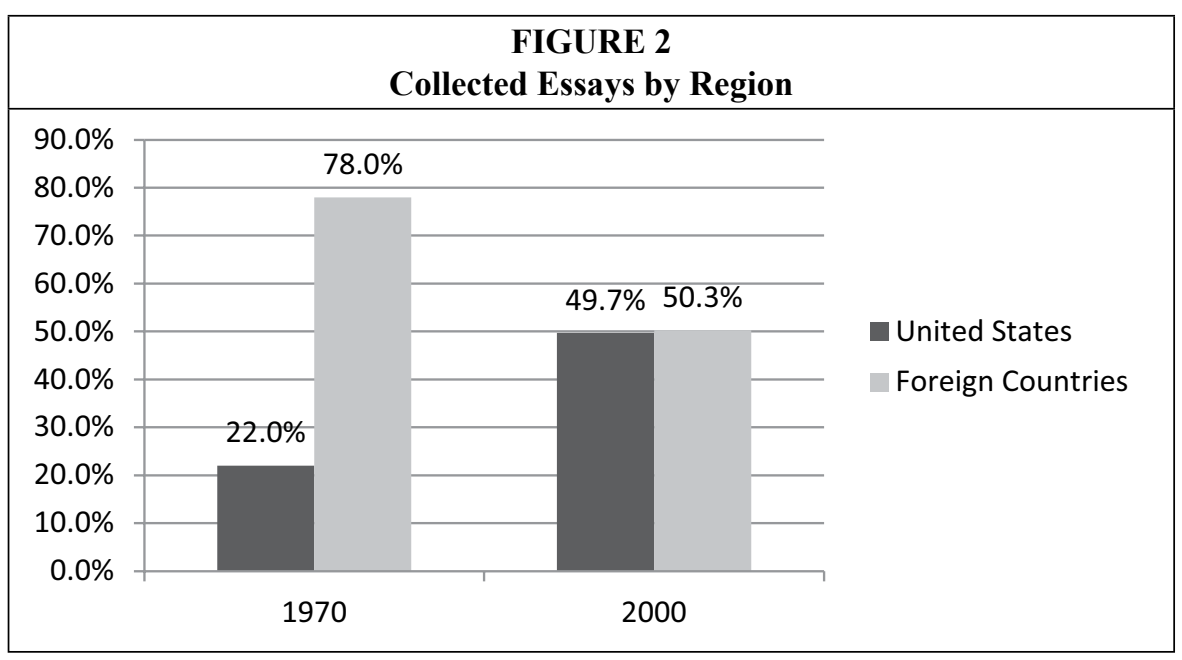




\begin{tabular}{|c|c|c|}
\hline \multicolumn{3}{|c|}{$\begin{array}{c}\text { TABLE } 7 \\
\text { References to Foreign Collected } \\
\text { Essays by Country of Publication }\end{array}$} \\
\hline & 1970 & 2000 \\
\hline Argentina & $8.2 \%$ & $13.4 \%$ \\
\hline Italy & $12.3 \%$ & $0.8 \%$ \\
\hline Mexico & $4.1 \%$ & $24.4 \%$ \\
\hline Spain & $42.5 \%$ & $23.6 \%$ \\
\hline Other Countries* & $32.9 \%$ & $37.8 \%$ \\
\hline Totals & $100.0 \%$ & $100.0 \%$ \\
\hline \multicolumn{3}{|c|}{$\begin{array}{l}* 8 \text { other countries in } 1970 \text { data, } 14 \text { other } \\
\text { countries in } 2000 \text { data. }\end{array}$} \\
\hline
\end{tabular}

up generally higher percentages of total references. For example, presses in the United States published 78 percent of the fine arts monographs included in his sample. ${ }^{32}$ In his study of philosophy monographs, he found that at least 50 percent of all cited books had some connection to U.S. publishing (either a U.S. press or a joint U.S./U.K. press)..$^{33}$ Although Thompson did not specifically report data for geography of publications, most of the frequently cited publishers she identified in her study of American and British literary studies were U.S.-based publishers. ${ }^{34}$

\section{Language of Source}

Tables 8 and 9 show the breakdown of references by type of publisher and language for scholarly monographs in the 1970 and 2000 data. These charts represent composite data for all three journals from a given year. The overall growth in references to English-language scholarly monographs from 1970 to 2000 is evident. In the 1970 data, English-language and Spanishlanguage monographs accounted for the same percentage of total references. However, the percentage of references to English-language monographs had grown by 8.3 percent from 1970 to 2000 , while all other language categories had declined.

\begin{tabular}{|l|c|c|c|c|c|c|}
\hline \multicolumn{7}{|l|}{ TABLE 8 } \\
References to Scholarly Monographs by Type of Press and Language, 1970 \\
Data \\
\hline Scholarly Monographs, 1970 & English & Spanish & Portuguese & French & German & Italian \\
\hline US University Presses & 69 & 2 & 0 & 0 & 0 & 0 \\
\hline Foreign University Presses & 8 & 13 & 0 & 4 & 0 & 0 \\
\hline $\begin{array}{l}\text { US Academic Institutions and } \\
\text { Departments }\end{array}$ & 4 & 0 & 0 & 0 & 0 & 0 \\
\hline $\begin{array}{l}\text { Foreign Academic Institutions } \\
\text { and Departments }\end{array}$ & 0 & 6 & 0 & 0 & 0 & 0 \\
\hline US Academic Trade Presses & 6 & 3 & 0 & 0 & 0 & 0 \\
\hline $\begin{array}{l}\text { Foreign Academic Trade } \\
\text { Presses }\end{array}$ & 4 & 64 & 7 & 7 & 3 & 1 \\
\hline US Popular Trade Presses & 20 & 0 & 0 & 0 & 0 & 0 \\
\hline Foreign Popular Trade Presses & 10 & 26 & 14 & 5 & 0 & 0 \\
\hline Government Entities & 0 & 7 & 0 & 2 & 0 & 0 \\
\hline Specialized Presses & 13 & 15 & 0 & 4 & 0 & 1 \\
\hline Joint Presses & 4 & 2 & 0 & 2 & 0 & 0 \\
\hline Totals & $\mathbf{1 3 8}$ & $\mathbf{1 3 8}$ & $\mathbf{2 1}$ & $\mathbf{2 4}$ & $\mathbf{3}$ & $\mathbf{2}$ \\
\hline Percentages & $\mathbf{4 2 . 3 \%}$ & $\mathbf{4 2 . 3 \%}$ & $\mathbf{6 . 4 \%}$ & $\mathbf{7 . 4 \%}$ & $\mathbf{0 . 9 \%}$ & $\mathbf{0 . 6 \%}$ \\
\hline
\end{tabular}

*Does not equal exactly $100 \%$ due to rounding. 


\begin{tabular}{|l|c|c|c|c|c|c|}
\hline \multicolumn{7}{|l|}{ TABLE 9 } \\
References to Scholarly Monographs by Type of Press and Language, \\
2000 Data
\end{tabular}

Tables 10 and 11 indicate an even greater change in the use of Englishlanguage sources. While references to volumes of collected essays showed up much less frequently in the 1970 data than in the 2000 data, Spanish-language sources made up the vast majority of those references, accounting for 60.6 percent of the total. Although still making up the largest group of references in the data from 2000, the percentage of references to Spanish-language sources declined by 13.2 percent. References to English-language collected essays, however, grew by 18.8 percent during the same time frame, making up 45.4 percent of all references to collected essays in the 2000 data. All other languages either declined as a percentage or rose only slightly. These data for references by language highlight a trend that was hinted at by the geographic data, with the pattern of growth in references to English-language sources seen in tables 10 and 11 reflecting the dramatic regional shift toward references to collected essays from the United States shown in figure 2.

As other studies of literary fields have reported, English-language scholarly works tend to be heavily referenced, typically lagging behind only the language of study. ${ }^{35}$ In this study, Spanish-language materials continue to make up a large proportion of the book-format resources that are referenced, but references to English-language resources are growing and even outpacing references to Spanishlanguage resources over time.

The percentages for English in the data for scholarly monographs and collected essays from 1970 and 2000 differ from previous studies in certain ways. In comparison to earlier studies of fine arts, Latin American history, English-language literature, or the humanities in general, the usage of English-language sources is much lower, although the overall growth in usage of English sources is similar to the pattern documented by Mendez and Chapman. ${ }^{36}$ When compared to other 


\begin{tabular}{|c|c|c|c|c|c|c|c|}
\hline \multicolumn{7}{|c|}{$\begin{array}{c}\text { TABLE } 10 \\
\text { References to Collected Essays by Type of Press and Language, } 1970 \text { Data }\end{array}$} & \\
\hline Collected Essays, 1970 & English & Spanish & Portuguese & French & German & Italian & \\
\hline US University Presses & 12 & 1 & 0 & 0 & 0 & 0 & \\
\hline Foreign University Presses & 3 & 0 & 0 & 0 & 0 & 0 & \\
\hline $\begin{array}{l}\text { US Academic Institutions } \\
\text { and Departments }\end{array}$ & 0 & 0 & 0 & 0 & 0 & 0 & \\
\hline $\begin{array}{l}\text { Foreign Academic } \\
\text { Institutions and Departments }\end{array}$ & 0 & 2 & 0 & 1 & 0 & 0 & \\
\hline US Academic Trade Presses & 3 & 0 & 0 & 0 & 0 & 0 & \\
\hline $\begin{array}{l}\text { Foreign Academic Trade } \\
\text { Presses }\end{array}$ & 0 & 32 & 5 & 0 & 0 & 4 & \\
\hline US Popular Trade Presses & 2 & 0 & 0 & 0 & 0 & 0 & \\
\hline $\begin{array}{l}\text { Foreign Popular Trade } \\
\text { Presses }\end{array}$ & 1 & 13 & 0 & 1 & 0 & 1 & \\
\hline Government Entities & 0 & 4 & 0 & 0 & 0 & 0 & \\
\hline Specialized Presses & 4 & 5 & 0 & 0 & 0 & 0 & \\
\hline Joint Presses & 0 & 0 & 0 & 0 & 0 & 0 & \\
\hline Totals & 25 & 57 & 5 & 2 & $\mathbf{0}$ & 5 & 94 \\
\hline Percentages & $26.6 \%$ & $60.6 \%$ & $5.3 \%$ & $2.1 \%$ & $0.0 \%$ & $5.3 \%$ & $100.0 \%$ * \\
\hline
\end{tabular}

TABLE 11

References to Collected Essays by Type of Press and Language, 2000 Data

\begin{tabular}{|c|c|c|c|c|c|c|c|}
\hline Collected Essays, 2000 & English & Spanish & Portuguese & French & German & Italian & \\
\hline US University Presses & 129 & 5 & 0 & 0 & 0 & 0 & \\
\hline Foreign University Presses & 13 & 8 & 1 & 0 & 0 & 0 & \\
\hline $\begin{array}{l}\text { US Academic Institutions and } \\
\text { Departments }\end{array}$ & 0 & 2 & 0 & 0 & 0 & 0 & \\
\hline $\begin{array}{l}\text { Foreign Academic Institutions } \\
\text { and Departments }\end{array}$ & 0 & 30 & 0 & 2 & 0 & 2 & \\
\hline US Academic Trade Presses & 21 & 10 & 0 & 0 & 0 & 0 & \\
\hline $\begin{array}{l}\text { Foreign Academic Trade } \\
\text { Presses }\end{array}$ & 9 & 56 & 0 & 5 & 1 & 0 & \\
\hline US Popular Trade Presses & 31 & 0 & 0 & 0 & 0 & 0 & \\
\hline Foreign Popular Trade Presses & 2 & 23 & 4 & 4 & 0 & 0 & \\
\hline Government Entities & 1 & 72 & 0 & 0 & 0 & 0 & \\
\hline Specialized Presses & 18 & 25 & 4 & 0 & 0 & 0 & \\
\hline Joint Presses & 5 & 8 & 13 & 0 & 0 & 0 & \\
\hline Totals & 229 & 239 & 22 & 11 & 1 & 2 & 504 \\
\hline Percentages & $45.4 \%$ & $47.4 \%$ & $4.4 \%$ & $2.2 \%$ & $0.2 \%$ & $0.4 \%$ & $100.0 \%$ \\
\hline
\end{tabular}


studies of foreign-language literature, the data from the current study indicate much higher percentages for English-language resources. For example, Cullars' studies of French, German, Italian, and Spanish literary studies reported that only 8-14 percent of references were to Englishlanguage sources. ${ }^{37}$

\section{Further Questions}

The data recorded for this study raise a number of interesting questions. It is important to consider the limitations of the sample size in interpreting the patterns described above. For example, the data reflect only the reference patterns from 140 articles gathered from two volumes of three different journals. A broader sample could show different patterns. In addition, the data from 2000 provide a snapshot of how reference characteristics changed in the journals since 1970, but they may not accurately reflect the current situation. With evidence of the differences between the 1970 data and the 2000 data and the differences between this study's findings and the numbers reported in other studies, there is reason to believe the patterns could have changed significantly since 2000 as well. Further studies are warranted to trace the consistency of the changes and trends reported here.

Other important questions include whether these patterns would look the same in a study of references in scholarly monographs from the field, rather than journal articles. Likewise, it is unclear whether the differences between the data reported here and the data in previous studies are a function of differing bibliometric methods or of differences in reference patterns over time. The most dramatic percentage change from the 1970 to 2000 data is the percentage decline in references to volumes of collected essays published by foreign academic trade presses. Although the data clearly demonstrate this decline, they do nothing to shed light on the factors behind it. The decline may be a function of the small 1970 data set and the large 2000 data set, but the factors behind this change are worth further exploration. Another question relates to the lack of joint-press publications found in this study. Although Cullars examined philosophy monographs that were written in English, the significant difference between the patterns seen here and his much higher percentage of joint-press publications is worth further investigation.

The language data lead to interesting questions as well. The remarkable growth in the references to English-language sources and the accompanying decline in references to material from other languages raises the question of what factors may be at play in this change (economic, scholarly, or otherwise). Is this a consequence of acquisitions decisions that influence availability of materials, or is it evidence of a broader pattern of scholars writing and citing for an international, English-speaking audience?

\section{Conclusion}

The results of this study confirm and challenge a number of assumptions about resources used by Spanish and Latin American literature scholars in their research, while also shedding additional light on the language-of-resource discussions that are of importance to librarians and scholars working in the humanities fields. This field exhibits many of the reference patterns of other areas of literary studies and other fields within the humanities. Scholarly monographs and volumes of collected essays are highly referenced resources that have grown in importance over the years between 1970 and 2000. U.S. university presses produce many of the monographs and volumes of collected essays that scholars are using, but foreign academic and popular trade presses and government entities are also publishing many highly referenced titles.

The scholarly monographs being referenced in the data are primarily coming from abroad, although a shift in references to volumes of collected essays produced in the United States is evident as well. 
The publishing trends in certain countries warrant special attention from selectors (Great Britain and Mexico for scholarly monographs, and Mexico and Spain for volumes of collected essays), but the geographic diversity beyond that requires selectors to be aware of broader publishing output across Europe and Latin America. Creating a list of core publishers from these data does not seem to be feasible because of the wide array of individual publishers represented. The growing usage of English-language items by scholars in this field is of interest, especially if the growth in percentage of English-language resources continues over time.

These results highlight the continued importance of selectors for Spanish and
Latin American literature who understand publishing trends in the United States and abroad, and who are familiar with the international acquisitions process for a broad array of items and geographic areas. These details-along with further study - provide a more nuanced picture of the needs of researchers in this field, which can be a helpful tool for experienced and novice selectors alike as they strive to best allocate scarce resources in the selection process.

\section{Acknowledgements}

Special thanks to my SALALM colleagues, Brad Brazzeal, and the $C \mathcal{E} R L$ reviewers for their helpful input and suggestions regarding this project."

\section{Notes}

1. Jennifer Knievel and Charlene Kellsey, "Citation Analysis for Collection Development: A Comparative Study of Eight Humanities Fields," Library Quarterly 75, no. 2 (2005): 142-68.

2. David S. Nolen, "Characteristics of la literatura: A Reference Study of Spanish and Latin American Literature," College \& Research Libraries 71, no. 1 (2010): 9-19; Jennifer W. Thompson, "The Death of the Scholarly Monograph in the Humanities? Citation Patterns in Literary Scholarship," Libri 52, no. 3 (2002): 121-36.

3. Robert N. Broadus, "Use by Humanists of University Press Publications," Scholarly Publishing 19, no. 1 (1987): 43-48; John Cullars, "Citation Characteristics of Monographs in the Fine Arts," The Library Quarterly 62, no. 3 (1992): 325-42; John Cullars, "Citation Characteristics of English-language Monographs in Philosophy," Library E Information Science Research 20, no. 1 (1998): 41-68; Meiyolet Mendez and Karen Chapman, "The Use of Scholarly Monographs in the Journal Literature of Latin American History," The Electronic Journal of Academic and Special Librarianship 7, no. 3 (2006), available online at http://southernlibrarianship.icaap.org/content/ v07n03/mendez_m01.htm [accessed 2 May 2012]; E. Stewart Saunders, "Library Circulation of University Press Publications," Journal of Scholarly Publishing 27, no. 3 (1996): 166-170; Thompson, "The Death of the Scholarly Monograph," 133.

4. John Cullars, "Citation Characteristics of Italian and Spanish Literary Monographs," The Library Quarterly 60, no. 4 (1990): 337-56; Nolen, "Characteristics of la literatura," 17.

5. Knievel and Kellsey, "Citation Analysis for Collection Development," 164.

6. Cullars, "Citation Characteristics of Monographs in the Fine Arts," 332.

7. Paul Metz and John Stemmer, "A Reputational Study of Academic Publishers," College $\mathcal{E}$ Research Libraries 57, no. 3 (1996): 234-47.

8. Broadus, "Use by Humanists of University Press Publications," 45.

9. Saunders, "Library Circulation of University Press Publications," 168-169.

10. Cullars, "Citation Characteristics of English-language Monographs in Philosophy," 49.

11. Thompson, "Death of the Scholarly Monograph," 130-33.

12. Mendez and Chapman, "Journal Literature of Latin American History."

13. Jordi Ardanuy, Cristóbal Urbano, and Lluís Quintana, "A Citation Analysis of Catalan Literary Studies (1974-2003)," Scientometrics 81, no. 2 (2009): 347-66.

14. Charlene Kellsey and Jennifer Knievel, "Global English in the Humanities? A Longitudinal Citation Study of Foreign-Language Use by Humanities Scholars," College E Research Libraries 65, no. 3 (2004): 194-204.

15. Knievel and Kellsey, “Citation Analysis for Collection Development," 147-65.

16. Richard Heinzkill, "Characteristics of References in Selected Scholarly English Literary Journals," Library Quarterly 50, no. 3 (1980): 352-65.

17. Robert N. Broadus, "Information Needs of Humanities Scholars: A Study of Requests 
Made at the National Humanities Center," Library and Information Science Research 9, no. 2 (1987): $113-29$.

18. John Cullars, "Characteristics of the Monographic Scholarship of Foreign Literary Studies by Native Speakers of English," College \& Research Libraries 49, no. 2 (1988): 157-70.

19. John Cullars, "Citation Characteristics of French and German Literary Monographs," Library Quarterly 59, no. 4 (1989): 305-25.

20. Cullars, "Citation Characteristics of Italian and Spanish Literary Monographs," 347.

21. Cullars, "Citation Characteristics of Monographs in the Fine Arts," 335-36.

22. Mendez and Chapman, "Journal Literature of Latin American History."

23. Ardanuy, Urbano, and Quintana, "A Citation Analysis of Catalan Literary Studies," 352.

24. Nolen, "Characteristics of la literatura," 11.

25. Cullars, "Citation Characteristics of English-language Monographs in Philosophy," 49; Helen Georgas and John Cullars, "A Citation Study of the Characteristics of the Linguistics Literature," College \& Research Libraries 66, no. 6 (2005): 496-515.

26. John M. Budd, "Academic Libraries and University Presses," Publishing Research Quarterly 7, no. 2 (1991): 27-37; Peter Givler, “University Press Publishing in the United States," in Scholarly Publishing: Books, Journals, Publishers, and Libraries in the Twentieth Century, eds. Richard E. Abel and Lyman W. Newlin, 107-20 (New York: Wiley, 2002); Albert N. Greco, "University Presses and the Trade Book Market: Managing in Turbulent Times," Publishing Research Quarterly 3, no. 4 (1988): 34-53.

27. Cullars, "Citation Characteristics of English-language Monographs in Philosophy," 49; Thompson, "The Death of the Scholarly Monograph," 133.

28. Broadus, "Use by Humanists of University Press Publications," 45; Cullars, "Citation Characteristics of Monographs in the Fine Arts," 332.

29. Cullars, "Citation Characteristics of English-language Monographs in Philosophy," 49.

30. Thompson, "Death of the Scholarly Monograph," 130.

31. Ibid., 132.

32. Cullars, "Citation Characteristics of Monographs in the Fine Arts," 332.

33. Cullars, "Citation Characteristics of English-language Monographs in Philosophy," 49.

34. Thompson, "The Death of the Scholarly Monograph," 130.

35. Cullars, "Citation Characteristics of French and German Literary Monographs," 317-18; "Citation Characteristics of Italian and Spanish Literary Monographs," 347; "Characteristics of the Monographic Scholarship of Foreign Literary Studies," 169.

36. Broadus, "Information Needs of Humanities Scholars," 127; Cullars, "Citation Characteristics of Monographs in the Fine Arts," 336; Heinzkill, "Characteristics of References in Selected Scholarly English Literary Journals," 361; Kellsey and Knievel, "Global English in the Humanities," 201; Knievel and Kellsey, "Citation Analysis for Collection Development," 150; Mendez and Chapman, "Journal Literature of Latin American History."

37. Cullars, "Citation Characteristics of French and German Literary Monographs," 317; "Citation Characteristics of Italian and Spanish Literary Monographs," 347. 